BMJ Paediatrics Open

\title{
Armed conflict and child mental health
}

\author{
Emma Pritchard, ${ }^{1}$ Imti Choonara ${ }^{2}$
}

To cite: Pritchard E, Choonara I. Armed conflict and child mental health. BMJ Paediatrics Open 2017;1:e000087. doi:10.1136/ bmjpo-2017-000087

Received 21 May 2017 Revised 11 July 2017 Accepted 12 July 2017

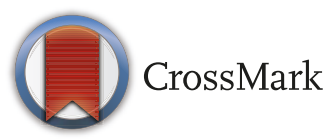

${ }^{1}$ Ecumenical Accompaniment Programme in Palestine and Israel (EAPPI), London, UK ${ }^{2}$ Academic Division of Child Health, University of Nottingham Derbyshire Children's Hospital, Derby, UK

Correspondence to Emeritus Professor Imti Choonara, Academic Division of Child Health, University of Nottingham, Derbyshire Children's Hospital, Derby, UK; Imti.Choonara@nottingham. ac.uk
Armed conflict affects at least one in six children worldwide. ${ }^{1}$ The number of child fatalities in areas of armed conflict is difficult to establish. Children may die directly from trauma. However, it is thought that even more die from starvation or infections following armed conflict in an area. ${ }^{1}$ Children who lose their parents in armed conflict are far more likely to develop infections or die from starvation. As well as experiencing direct injuries, children may be affected in many ways. Health and educational facilities are often destroyed during armed conflict. The psychological impact of witnessing armed conflict is increasingly being recognised as a major problem for children. ${ }^{23}$ The aim of this editorial is to highlight both the problem and approaches to address the problem.

A systematic review of papers on the mental health of children and adolescents in Middle East, up to 2010 identified 71 papers. ${ }^{3}$ The prevalence of post-traumatic stress disorder (PTSD) in children and adolescents was found to be $23 \%-70 \%$ in Palestine, $10 \%-30 \%$ in Iraq and $5 \%-8 \%$ in Israel. $^{3}$ Studies in Rwanda following the genocide in 1994 detected rates of PTSD in children and adolescents of 54\%-62\%. ${ }^{4}$ Mental health disorders are clearly a significant problem for young people and children in areas of armed conflict.

Concern has been raised that children exposed to armed conflict are more likely to develop long-term aggressive behaviour themselves. ${ }^{5}$ Attacks occurring on schools are particularly distressing for children. A study in Bosnia reported that a lack of a family member present during an attack at school was one of the most frightening experiences during armed conflict. ${ }^{6}$ It is thought that many of the adverse effects resulting from witnessing armed conflicts decrease with length of time from exposure. It is noted however that some effects are long term. ${ }^{6}$ A recent report by Save the Children has expressed major concern regarding the effects of armed conflict on the mental health of children in Syria. ${ }^{7}$

Despite the extensive evidence of the adverse effects of armed conflict on the mental health of children and adolescents, ${ }^{3}$ there has been far less research on interventions to try and minimise the long-term effects on mental health. A recent systematic review only identified 24 studies, evaluating interventions for children affected by armed conflict in low-income and middle-income countries. ${ }^{2}$ Encouragingly, the interventions appear to show promising results on both mental health and psychological well-being. The most frequently used interventions were creative expressive, psycho-educational and cognitive strategies. The creative expressive strategies included interactive activities such as drama, music, role-playing and drawing. ${ }^{2}$

Adverse mental health problems in Palestinian children and adolescents have been well documented. ${ }^{389}$ The Ecumenical Accompaniment Programme in Palestine and Israel (EAPPI) works in areas of armed conflict to reduce conflict and protect innocent civilians. In particular, they work alongside UNICEF in schools to minimise the negative effects of the conflict on children and their education. In 2015, the UN documented 96 cases of schools coming under fire during military operations, and 46 attacks and threats of violence against students and teachers by Israeli Security Forces and settlers. ${ }^{10}$ Ecumenical Accompaniers (EAs) work to support students and teachers in schools to minimise the harmful effects and disruption to education caused by such attacks. Their support includes providing protective presence for students as they journey to and from school; responding to and reporting on attacks on schools and discussing with Israeli Security Forces on how best to balance their security requirements with the psychological and educational needs of the children. EAPPI has been accompanying children to school in Palestine since 2002. Accompanying the children provides both protection during the journey and psychological reassurance, which is important in long term. On some occasions, EAs have been able to reduce their presence at schools when relationships with Israeli Security Forces and local settler populations have de-escalated, for example, visits to Burin Secondary Mixed School were reduced to once a week in 2015. UNICEF, in partnership 


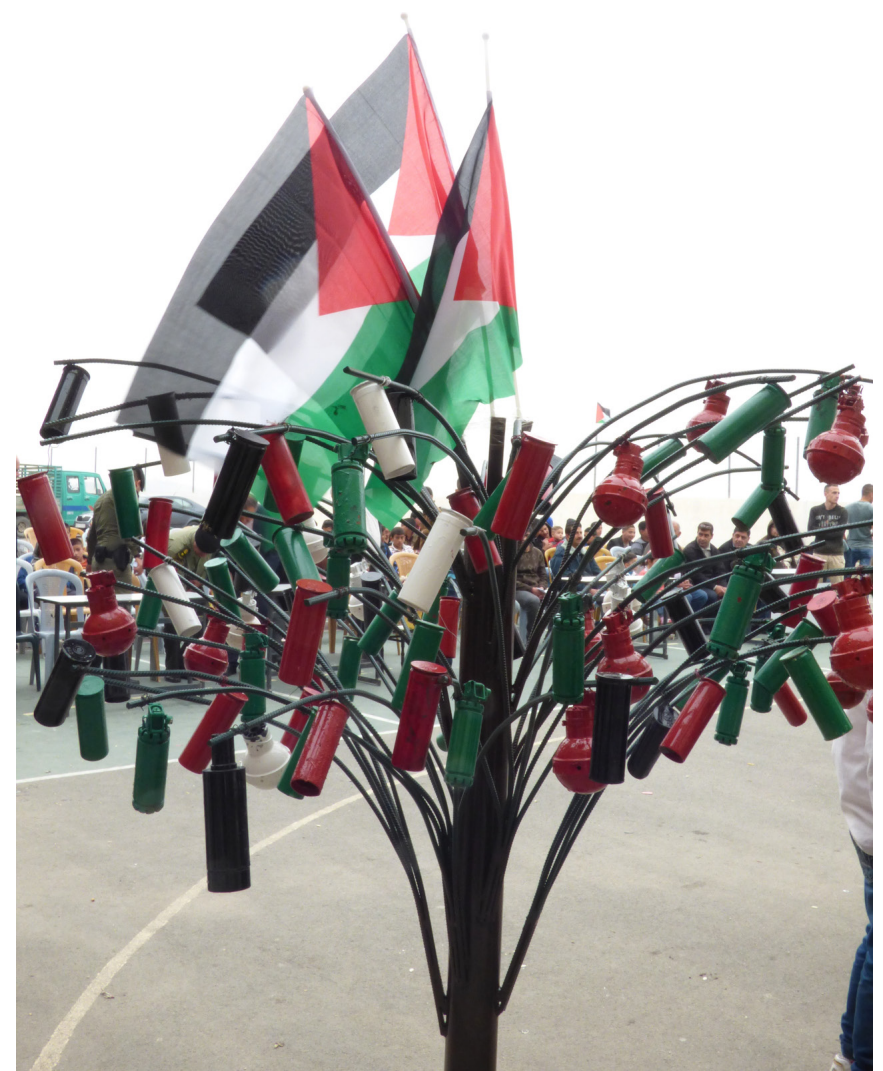

Figure 1 Tree made from tear gas and sound grenade cannisters. Urif Secondary Mixed School, Emma Pritchard/ EAPPI 2015.

with EAPPI and Christian Peacemakers Teams worked to protect 4334 Palestinian children and 333 teachers from schools across the West Bank from harassment and risks of violence in 2016.

This picture was taken in Urif Secondary Boy's School in the north of occupied Palestine in April 2015 (figure 1). This tree, painted in the colours of the Palestinian flag, is made of empty sound grenade and tear gas canisters which have been used against the school. Sound grenades produce a blinding flash of light and an intensely loud noise, which impair vision, hearing and balance for a short period of time. ${ }^{11}$ The noise generated by sound grenades in is the range of $140-170 \mathrm{db} .^{11}$ This however may be amplified by confined spaces which may result in ruptured eardrums and other inner ear damage. As well as causing temporary incapacitation from disorientation, nausea, vomiting, vertigo and diarrhoea have also been reported. ${ }^{11}$ The use of the sound grenades and tear gas causes significant psychological trauma to the schoolchildren. By actively involving the children and young people in the school in a positive non-violent activity, it is hoped that adverse mental health problems will be minimised. Each year, the schools have tried to use the weapons used against the schools in a creative manner. In 2014, the empty canisters had been used by the children to spell out 'نيطسل' (Palestine). Other schools also use creative activities to support the mental health of the children, for example, in an activity in May 2015 at Burin Secondary Mixed School younger children were encouraged to paint a banner showing their experience of being a child in Palestine. The creative activities are initiated by the teachers and supported by EAPPI and other organisations, such as Defence for Children International, Christian Peacemakers Team, Medecins Sans Frontieres and the YMCA. These creative activities have not been formally evaluated as yet.

Armed conflict has a major negative effect on the mental health of children and adolescents. The evidence basis for the effectiveness of interventions to minimise the effects is poor. Initiatives such as that coordinated by EAPPI are to be welcomed. It is to be hoped that health professionals can work alongside organisations such as EAPPI, in both supporting such interventions and also evaluating their effectiveness.

Competing interests Obtained.

Provenance and peer review Commissioned; externally peer reviewed.

Open Access This is an Open Access article distributed in accordance with the Creative Commons Attribution Non Commercial (CC BY-NC 4.0) license, which permits others to distribute, remix, adapt, build upon this work non-commercially, and license their derivative works on different terms, provided the original work is properly cited and the use is non-commercial. See: http://creativecommons.org/ licenses/by-nc/4.0/

(c) Article author(s) (or their employer(s) unless otherwise stated in the text of the article) 2017. All rights reserved. No commercial use is permitted unless otherwise expressly granted.

\section{REFERENCES}

1. Rieder M, Choonara I. Armed conflict and child health. Arch Dis Child 2012;97:59-62.

2. Jordans MJ, Pigott $\mathrm{H}$, Tol WA, et al. Interventions for Children affected by Armed Conflict: a systematic review of Mental Health and Psychosocial support in low- and Middle-Income Countries. Curr Psychiatry Rep 2016;18:9.

3. Dimitry L. A systematic review on the mental health of children and adolescents in areas of armed conflict in the Middle East. Child Care Health Dev 2012;38:153-61.

4. Neugebauer R, Fisher PW, Turner JB, et al. Post-traumatic stress reactions among rwandan children and adolescents in the early aftermath of genocide. Int J Epidemiol 2009;38:1033-45.

5. Qouta S, Punamäki RL, Miller T, et al. Does war beget child aggression? Military violence, gender, age and aggressive behavior in two palestinian samples. Aggress Behav 2008;34:231-44.

6. Jones L, Kafetsios K. Exposure to political violence and psychological Well-being in bosnian adolescents: a mixed method approach. Clin Child Psychol Psychiatry 2005;10:157-76.

7. Save the Children FundSave the Children Fund. Stop invisible wounds. The impact of six years of war on the mental health of Syria's children 2017.

8. Lokuge K, Shah T, Pintaldi G, et al. Mental health services for children exposed to armed conflict: médecins Sans Frontières' experience in the democratic republic of Congo, Iraq and the occupied palestinian territory. Paediatr Int Child Health 2013;33:259-72.

9. Thabet AM, Tawahina AA, Sarraj EE, et al. Comorbidity of post traumatic stress disorder, attention deficit with hyperactivity, conduct, and oppositional defiant disorder in palestinian children affected by war on Gaza. Health 2013;05:994-1002.

10. General Assembly Security Council Report. Children and armed conflict: report of the Secretary-General. http://www. securitycouncilreport.org/atf/cf/\%7B65BFCF9B-6D27-4E9C-8CD3CF6E4FF96FF9\%7D/s_2016_360.pdf (accessed 20 Apr 2016).

11. Robertson AG. Less than lethal weapons: the medical effects of non-lethal weapons - a review. Australian Military Medicine 2005; $14: 66-70$ 